\title{
THE EFFICIENCY OF FIRMS IN THE UNORGANISED MANUFACTURING SECTOR IN WEST BENGAL
}

\author{
Ujjwal Seth \\ Assistant Professor in Economics, \\ Government College of Engineering \& Textile Technology, \\ Murshidabad, West Bengal, India
}

\begin{abstract}
In this paper attempts have been made to calculate the technical efficiency of unorganised manufacturing firms in the state of West Bengal using unit level data of NSSO $73^{\text {rd }}$ round. In this process Data Envelopment Analysis has been used. The analysis shows wide variation in efficiency in the different sectors of the state. Attempts have been made to explain the differences in the efficiency scores. It is found that several factors are responsible for the differences of efficiency. Among these the location of enterprise and the restriction on the firm in the form of registration are also some factors that affects the efficiency of firms negatively.
\end{abstract}

JEL Classification: D24, J46, O17

Key words: Efficiency, NSSO, OAE, Establishment, Firms, DEA

Cite this Article: Ujjwal Seth, The Efficiency of Firms in the Unorganised Manufacturing Sector in West Bengal, International Journal of Electrical Engineering and Technology (IJEET), 12(5), 2021, pp. 116-127. https://iaeme.com/Home/issue/IJEET?Volume=12\&Issue $=5$

\section{INTRODUCTION}

The unorganised sector is very much important in a country. It contributes a major share in terms of employment. This sector also provides cheap commodities in the economy. The firms in unorganised sector require less capital. These firms operate on household labour but use of hired labour is not very uncommon.

The unorganised manufacturing sector is a major employment generating sector in India. Many unskilled labour can find job in this sector. Firms in the unorganised sector are very small in size.

The present study is based on the unorganised manufacturing sector in West Bengal. In India West Bengal occupies a distinct position in the sphere of unorganised manufacturing sector. West Bengal comes first in the number of unorganised manufacturing enterprises. This

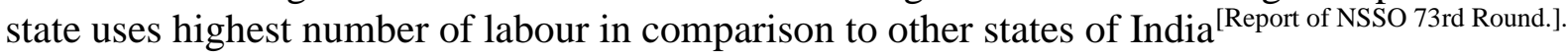
In terms of output produced West Bengal occupies third position in India. Thus, it is imperative 
to know how efficiently the firms in West Bengal are run in this sector and on what factors their efficiency hinge on.

The paper is organised as follows. In section 2 a brief review of exiting literature is given. Section 3 gives the brief description of the data used. Section 4 provides methodology used. In section 4 some features of data are discussed. Section 5 gives the distribution of efficiency score. Section 6 tries to relate the efficiency score with some socio-economic parameters. Finally, conclusion is drawn in section 7.

\section{A BRIEF VIEW OF THE EXISTING LITERATURE:}

Efficiency is a term which is normally applicable to firms in the organised sector. Firms in the unorganised sector are very small and sometimes the input and output are not clearly defined. However, it is very much important to find out the efficiency in this sector also. The efficiency scores will provide a basis for the further analysis. Efficient firms uses the inputs optimally. So, the efficiency analysis will provide insight into the firm's performance in the sector. A few attempts have been made to find out the efficiency in the sector.

Bairagya (2013) tried to find out the impact of regulation on the firms in the informal sector. Using the NSSO data he conducted his analysis and found that in the case of the developed states like Delhi, firms on contracts are less efficient. The analysis raises question on the enforcement of regulation which leads to inefficiency.

Raj (2011), analysed the technical efficiency in the unorganised manufacturing sector of Kerala. He used translog stochastic production function. He found that unorganised manufacturing sector firms in Kerala are highly technical efficiency. Size, ownership, location and seasonality affect efficiency. Credit availability and hired labour boost the level of technical efficiency.

Sengupta. A, Dutta S.K, Mondal. S (2011), studied wage-productivity differential between male and female workers in the unorganised service sector. They found that females in establishments are more productive than males while the opposite holds in the case of OAEs. They also noted that females are being discriminated against male though productivity of the female worker has increased.

Kathuria, Raj and Sen (2010) analysed the productivity and performance of the unorganised manufacturing sector for major 15 states for the period 1994-95 to 2005-06. They used the National Sample Survey (NSS) unit level data. They measured productivity by using both partial (labour productivity) and Total Factor Productivity (TFP). The Cobb-Douglas Production Function has been estimated by Levinsohn and Petrin method, which considers the potential simultaneity bias in the estimation of production function. The analysis show the fluctuating labour in the unorganised sector. The productivity has grown at a rate of 7 percent during the first period, viz. 1995-2001, but then fell considerably during the second period, viz. 2001-2006. They noticed that the capital-labour ratio has been increased in this period in all states but the growth slowed down during the second period. It has also been found that capital intensity acted as the major driver of labour productivity in the sector. They found that total factor productivity declined steadily in the sector similar to the trend of labour productivity.

Sengupta, A, Datta S.K, and Modal. S (2009) attempted to measure surplus labour in the informal service sector of India using the NSSO data. The used the concept of sub-vector efficiency which is developed by Ray (2005). The conducted the analysis to find the gender specific estimate of the surplus labour. Their analysis show that there are wide fluctuation of the extent of surplus labour. The measured value of surplus labour is then regressed on a number of macro parameters. They tried to explain the extent of surplus labour by conducting regression analysis. They found that migration rate is an important factor in explaining the differences in the surplus labour. 


\section{SOURCE AND NATURE OF DATA}

Here study the unit level data of 73rd round of NSSO (National Sample Survey Office) has been used. The data is based on the survey on Unincorporated Non-Agricultural Enterprises (Excluding Construction) in India conducted during July 2015 to June 2016. For our present study we have used this data for West Bengal, a state of India.

In the data enterprises were categorised into two types, the first is the Own Account Enterprises (OAE). These basically operates on the household labour and does not employ hired labour of fairly regular basis in the reference year. The second type is Establishments which employ at least one hired labour on a fairly regular basis in the reference year. The eligibility criteria for an enterprise to be covered in the survey was at least 30 days of operation (15 days of operation for seasonal enterprises / SHGs) in the reference year i.e. "last 365 days preceding the date of survey".

The output is measured by gross value added (GVA). It has been calculated by deducting 'total operating expenses' from 'total receipts'. The total amount of labour force is measured by the number of workers employed in that enterprise. A 'worker' is defined to be a person who participated either full time or half time in the activity of the enterprise. By this definition workers include own labour, family workers, hired workers and others. Capital is measured by the amount of fixed assets. They include assets held for the purpose of producing or providing goods and services necessary for production activity. It does not include assets held for resale. According to NSSO definition such assets include (i) land, (ii) building, (iii) plant and machinery, (iv) transport equipment and (v) tools and other fixed assets. The principal operating expenses constitute the sum of the expenses of the following activities- (i) the manufacturing activity, (ii) trading activity -value of other commodity purchased, expenses incurred on transportation activities, (iii) warehousing and support activities, (iv) postal and courier activities, (v) accommodation and food services activities, (vi) information and communications, (vii) financial and insurance activities, (viii) real estate activities, (ix) educational activity and (x) human health and social activity. The data provide rich crosssectional information that can be fruitfully harnessed to understand various aspects of unorganised manufacturing sector.

\section{METHODOLOGY}

In order to conceptualize the notion of efficiency, consider a set-up of $\mathrm{m}$ different outputs:

$y \in R_{+}^{m}$ and $\mathrm{n}$ different inputs $x \in R_{+}^{n}$. For any output bundle $y$ it is possible to define the input requirement set as:

$$
V(y)=\{x: x \text { can produce } y\}
$$

Production theory imposes certain restrictions on the structure of $V(y)$ (Varian 1984).

1. Feasibility: If $\left(x^{j}, y^{j}\right)$ is actually observed then $x^{j} \in V\left(y^{j}\right)$. All observed input-output bundles are feasible.

2. Convexity: V (y) is a convex set.

3. Free disposability of inputs: If $\left(\mathrm{x}^{0}, \mathrm{y}^{0}\right)$ is feasible then for any $x \geq x^{0},\left(\mathrm{x}, \mathrm{y}^{0}\right)$ is also feasible.

4. Free disposability of outputs: If $\left(\mathrm{x}^{0}, \mathrm{y}^{0}\right)$ is feasible then for any $y \leq y^{0},\left(\mathrm{x}^{0}, \mathrm{y}\right)$ is also feasible.

Based on this set, DEA measures are defined. An input oriented radial measure of technical efficiency of a firm producing output $y^{0}$ from inputs $x^{0}$ is

$$
\mathrm{E}_{\mathrm{f}}^{*}=\frac{1}{\theta_{f}^{*}} \text { Where } \theta_{f}^{*}=\min \theta_{f}: \theta_{f} x^{0} \in V\left(y^{0}\right)
$$


The BCC (Banker, Charnes and Cooper 1984) measure of efficiency is defined as:

$$
\min _{\theta_{f} \lambda} \theta_{f}
$$

Subject to:

$y_{f} \leq Y \lambda$,

$\mathrm{X} \lambda \leq \theta_{f} x_{f}$

$\sum \lambda_{f}=1$

For our empirical exercise, we have considered a single output multi-input set-up. The inputs considered are of three types- capital input (K), Operating Expenses (OP), labour input (L).

DEA uses the Linear Programming technique to construct efficient frontiers and the corresponding input efficiency following the above specifications. We give a simple illustration of the method following Farrell (1957). Assuming constant returns to scale, production function can be reduced to a single isoquant by a constant division $\mathrm{Y}$, the level of output, as $\mathrm{F}\left(x_{1}, x_{2}\right)$ $=1$ Assuming constant returns to scale and convexity, the unit isoquant may be approximated by negatively sloped convex hull. Farrell postulated a non-parametric technique to construct these convex hulls from the observed input-output data.

We illustrate the basic technique of Farrell (1957) with the figure below:

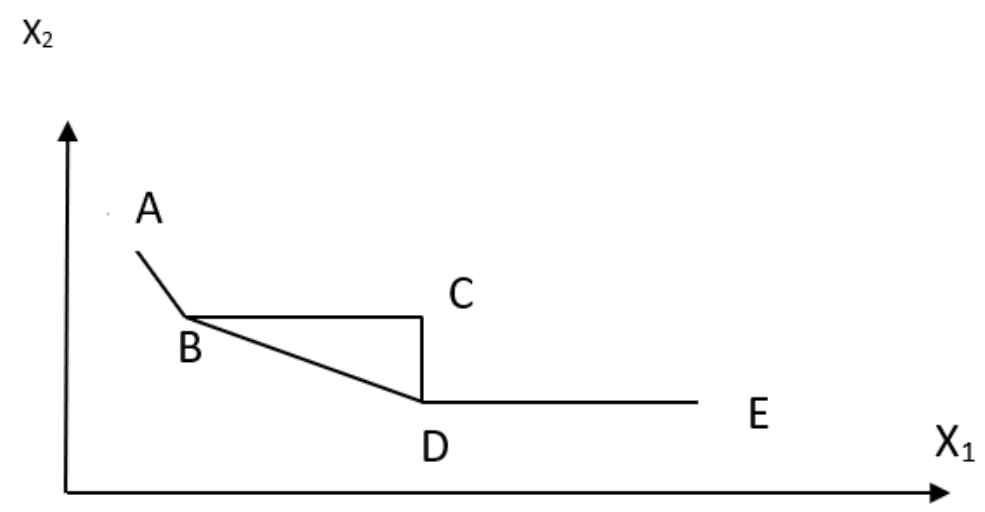

\section{Figure 1}

In the above figure we have five observations (A,B, C, D and E) of levels of inputs that produce unit output. Following Farrell's technique, the constructed convex hull is ABDE. It is the non-parametric technique of Farrell that is generalized as DEA by Banker, Charnes and Cooper (1984). In a multi-input multi-output structure, the convex hulls representing frontier technology could be constructed using linear programming technique within the DEA structure. This constructed isoquant gives us information of the empirical input requirement set $(\mathrm{L}(\mathrm{y}))-$ a generalization of the production function. An input requirement set L(y) gives us all the possible combination of inputs that can produce a given level of pre-specified output- $y$. In our example above we can construct the input requirement set corresponding to unit output level $(y$ $=1)$. Given an input requirement set L(y), it thus becomes pertinent to study how "far" a point in the input requirement set $\mathrm{L}(\mathrm{y})$ is away from the isoquant. Efficiency analysts utilized this idea to develop the idea of distance function. The distance functions measure distances radially (along a ray through the origin passing the point). Input distance function gives us the value of the scalar by which we can scale down a given input combination remaining within the input requirement set. On the other hand, input radial efficiency (Debreu-Farrell) can be defined as 
the extent to which current input can be scaled down without reducing the output. Hence input efficiency measure is just a reciprocal of input distance function.

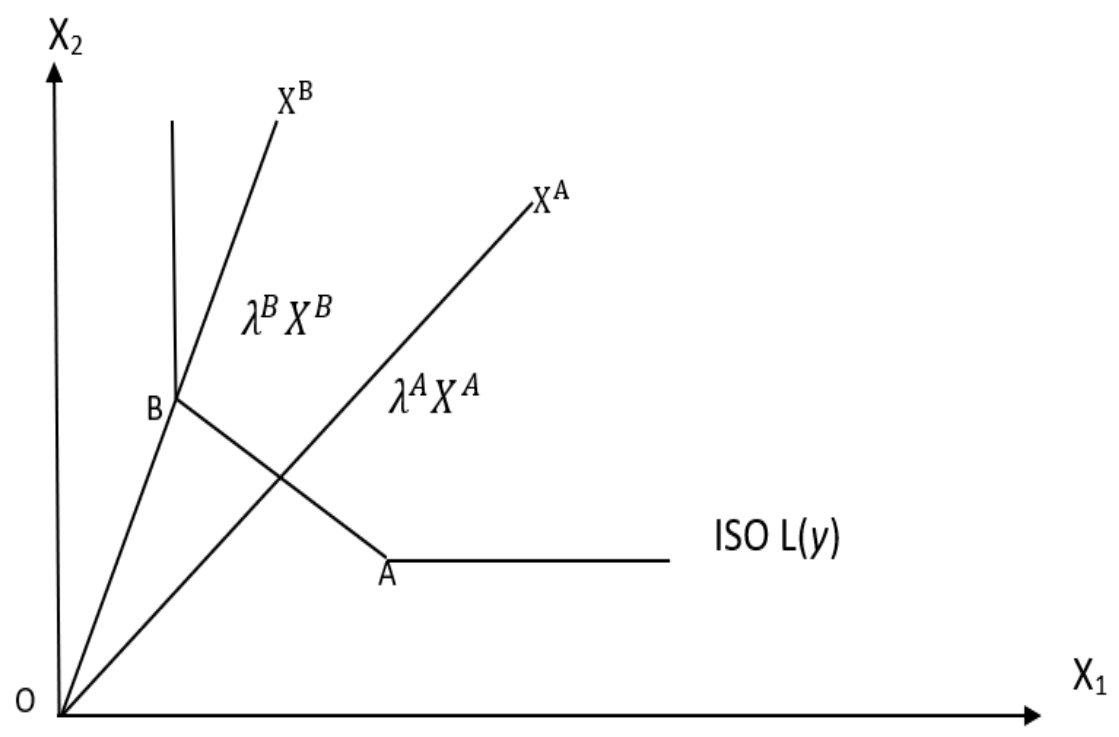

Figure-2

In figure 2 , when we scale down from the point $X^{A} \equiv\left(X_{1}^{A} X_{2}^{A}\right)$ to the point $\lambda^{A} X^{A} \equiv$ $\left(\lambda^{A} X_{1}^{A}, \lambda^{A} X_{2}^{A}\right)$ with $0 \leq \lambda^{A}<1$, we reach the Iso $\mathrm{L}(\mathrm{y})$. Similarly, we reduce from $X^{B}$ to $\lambda^{B} X^{B}$ to reach Iso $\mathrm{L}(\mathrm{y})$. In our above example, then $\lambda^{A}$ is the efficiency index for the observation $\mathrm{A}$ and $\lambda^{B}$ for observation B. The BCC (Banker, Charnes and Cooper) method generalizes this basic concept for the many-input many- output case.

For our purpose we have used one output (GVA) and three inputs - capital, labour used and operating cost. Using DEAP software we have input oriented VRS technical efficiency of firms. The next section discusses the distribution of efficiency scores.

\section{DESCRIPTION OF FIRMS IN THE UNORGANISED MANUFACTURING SECTOR IN WEST BENGAL OF INDIA}

Firms in the unorganised manufacturing sector are basically small firms which uses less amount of labour and capital. We have used NSSO $73^{\text {rd }}$ round data which provides the detailed information of the operation of the firms in this sector. The firms in the unorganised sector are subdivided into two categories - the Own Account Firms (OAE) and the Establishment firms. The OAE firms are basically household firms using mainly household labour. The Establishment firms are the business firms which use hired labour in their operation. In this section we shall discuss some features of the firms in the unorganised manufacturing sector in West Bengal.

Table 1 Summary statistics for Manufacturing OAE enterprise

\begin{tabular}{|l|c|c|c|}
\hline \multicolumn{4}{|c|}{ Firm: Manufacturing OAE } \\
\hline \multicolumn{1}{|c|}{ Variables } & Mean & S.D & C.V \\
\hline Gross Value Added (Rs.) & 6271 & 8941 & 142.58 \\
\hline Capital (Rs.) & 75851 & 127248 & 167.76 \\
\hline Operating Cost(Rs.) & 13272 & 38199 & 287.82 \\
\hline Labour & 1.417 & 1.654 & 160.70 \\
\hline
\end{tabular}

Source: Authors calculation from NSSO $73^{\text {rd }}$ Round data 
The above table shows that the mean GVA for the manufacturing firm is Rs. 6271. The mean value of capital used is Rs. 75851. The mean value of the operating cost is Rs. 13272. The average use of labour is 1.417 . All the variables show high coefficient of variation.

Table 2 Summary statistics for Manufacturing Establishment enterprise

\begin{tabular}{|l|c|c|c|}
\hline \multicolumn{4}{|c|}{ Firm: Manufacturing Establishment } \\
\hline \multicolumn{1}{|c|}{ Variables } & Mean & S.D & C.V \\
\hline Gross Value Added (Rs.) & 56336 & 119516 & 212.15 \\
\hline Capital (Rs.) & 415457 & 837116 & 201.49 \\
\hline Operating Cost(Rs.) & 109984 & 339203 & 308.41 \\
\hline Labour & 8 & 18 & 230.70 \\
\hline
\end{tabular}

Source: Authors calculation from NSSO $73^{\text {rd }}$ Round data

Table 2 shows the summary statistics of manufacturing establishment firms. Here we see that average value of Gross Value Added is Rs. 56336. The mean value of the capital used by the firms is Rs. 415457. The mean value of the Operating Cost is Rs. 109984 whereas, the average labour usage is 8 .

Comparing the OAE and Establishment firms, we see that the mean values of GVA, Capital, Operating Cost and Labour usage is higher in Establishment firms.

The following table (Table-3) shows the operational features of the manufacturing OAE firms in Rural and in Urban areas. Here we see that labour usage per firm is 1.37 in Rural sector whereas it is 1.29 in the Urban sector. The urban firms uses more capital. Capital per firm is Rs. 25666 in rural sector whereas for Urban firms the value is Rs. 61697. Capital-Labour ratio is also higher for urban firms(47848.59) than the rural firms (18792.26). For rural sector the GVA per labour is Rs. 20556.40 and this value is Rs. 38949.68 for urban firms.

Table 3 Operational fe₹atures of Manufacturing OAE firms

\begin{tabular}{|l|c|c|c|}
\hline & \multicolumn{3}{|c|}{ Manufacturing OAE } \\
\hline & Rural & Urban & Total \\
\hline Labour per firm & 1.37 & 1.29 & 1.35 \\
\hline Capital per firm (Rs.) & 25666 & 61697 & 33847 \\
\hline Capital -Labour Ratio & 18792.26 & 47848.59 & 25100.58 \\
\hline GVA per labour (Rs.) & 20556.40 & 38949.68 & 24549.70 \\
\hline
\end{tabular}

Source: Author's calculation from NSSO 73rd Round data

Table -4 shows the operational features of the manufacturing establishment firms of West Bengal of India. From the table we can see that labour usage per firm is 5.45 for rural areas whereas for urban area this value is 4.46. The Capital usage per firm in rural sector is Rs. 219635 but in the urban sector the value is Rs. 374876. Capital-Labour ratio is higher in urban firm (Rs. 84128.29) in comparison to the rural firms (Rs. 40339.51). GVA per firms are also higher for urban firms (Rs. 94112.64) than firms in the rural sector (Rs. 74945.44). 
Table 4 Operational features of Manufacturing Establishment firms.

\begin{tabular}{|l|c|c|c|}
\hline & \multicolumn{3}{|c|}{ Manufacturing OAE } \\
\hline & Rural & Urban & Total \\
\hline Labour per firm & 5.45 & 4.46 & 4.91 \\
\hline Capital per firm (Rs.) & 219635 & 374876 & 303940 \\
\hline Capital -Labour Ratio & 40299.51 & 84128.59 & 61899.36 \\
\hline GVA per labour (Rs.) & & & 84391.42 \\
\hline
\end{tabular}

Source: Author's calculation from NSSO 73rd Round data

Table- 5 shows the problem faced by the firms in Manufacturing OAE firms. Here we see that most important problem faced is the others category. Shrinkage/ falling of demand is the second most important problem faced by these firms. Labour dispute is the least important problem for the small firms.

Table 5 Percent of Manufacturing OAE firms according to nature of the problem faced.

\begin{tabular}{|l|l|}
\hline erratic power supply & 5.62 \\
\hline shortage of raw materials & 4.06 \\
\hline shrinkage /fall of demand & 35.45 \\
\hline non-availability / high cost of credit & 12.21 \\
\hline non-recovery of financial dues & 4.01 \\
\hline non-availability of labour & 0.82 \\
\hline non-availability of skilled labour & 0.21 \\
\hline labour disputes & 0.01 \\
\hline others & 37.62 \\
\hline & \\
\hline Total & 100.00 \\
\hline
\end{tabular}

Source: Author's calculation from NSSO 73rd Round data

Form table 6 we see that the most important problem for the Establishment firms is the shrinking/falling demand. The second most important problem is the problem of other category. Non-availability/ higher cost of credit is also an important problem. Here also we see that labour dispute is a minor problem.

Table 6 Percent of Manufacturing Establishment firms according to nature of the problem faced.

\begin{tabular}{|l|l|}
\hline erratic power supply & 5.24 \\
\hline shortage of raw materials & 2.09 \\
\hline shrinkage /fall of demand & 28.26 \\
\hline non-availability / high cost of credit & 17.34 \\
\hline non-recovery of financial dues & 9.24 \\
\hline non-availability of labour & 5.93 \\
\hline non-availability of skilled labour & 9.92 \\
\hline labour disputes & 0.85 \\
\hline others & 21.12 \\
\hline & \\
\hline Total & 100.00 \\
\hline
\end{tabular}

Source: Author's calculation from NSSO 73rd Round data 
The following table (Table 7) shows the how the OAE firms received the assistance from the government. Here we see that most important assistance is in the form of financial loans. The second most important help form the government is the skill-development. Subsidy also is an important assistance received by these firms.

Table 7 Percent of Manufacturing OAE firms according to types of government aid received.

\begin{tabular}{|l|l|}
\hline financial loan & 59.44 \\
\hline subsidy & 17.46 \\
\hline machinery & 1.75 \\
\hline skill development & 21.25 \\
\hline others & 0.11 \\
\hline & \\
\hline Total & 100 \\
\hline
\end{tabular}

Source: Author's calculation from NSSO 73rd Round data

The assistance from the government received by Establishment firms are shown in the table 8 below. Here we see that most single important form of assistance is the financial loans. There is no assistance for the skill development.

Table 8 Percent of Manufacturing Establishment firms according to types of government aid received.

\begin{tabular}{|l|l|}
\hline financial loan & 89.77 \\
\hline subsidy & 5.28 \\
\hline machinery & 2.80 \\
\hline skill development & 0 \\
\hline others & 2.16 \\
\hline & \\
\hline Total & 100 \\
\hline
\end{tabular}

Source: Author's calculation from NSSO 73rd Round data

\section{DISTRIBUTION OF EFFICIENCY SCORE}

Form the following table (Table 9), we see that the efficiency score for the OAE firms is higher than the Establishment firms. Rural firms are less efficient than the urban counterpart.

Table 9 Sector wise efficiency scores of the OAE and Establishment firms.

\begin{tabular}{|l|c|c|c|}
\hline \multicolumn{1}{|c|}{ Sector } & OAE & ESTA & Total \\
\hline Rural & 0.829 & 0.341 & 0.539 \\
\hline Urban & 0.865 & 0.349 & 0.561 \\
\hline Total & 0.846 & 0.345 & 0.549 \\
\hline
\end{tabular}

Source: Author's calculation from NSSO 73rd Round data

From table 10 we see that the highest efficiency score districts are - Darjiling (0.659),

Dakshin Dinajpur (0.650), Maldah (0.625) and Jalpaiguri (0.623). On the other hand, lowest scoring districts are Nadia (0.461), North Twenty Four Parganas (0.486) and Murshidabad (0. 498) respectively. 
Table 10 Sector wise efficiency scores of the firms in the districts of West Bengal.

\begin{tabular}{|l|c|}
\hline \multicolumn{1}{|c|}{ District } & $\begin{array}{c}\text { mean } \\
\text { efficiency }\end{array}$ \\
\hline Darjiling & 0.659 \\
\hline Jalpaiguri & 0.623 \\
\hline Koch Bihar & 0.581 \\
\hline Uttar Dinajpur & 0.508 \\
\hline Dakshin Dinajpur & 0.650 \\
\hline Maldah & 0.625 \\
\hline Murshidabad & 0.498 \\
\hline Birbhum & 0.593 \\
\hline Barddhaman & 0.580 \\
\hline Nadia & 0.461 \\
\hline North Twenty Four Parganas & 0.486 \\
\hline Hugli & 0.529 \\
\hline Bankura & 0.560 \\
\hline Puruliya & 0.564 \\
\hline Haora & 0.509 \\
\hline Kolkata & 0.595 \\
\hline South Twenty Four Parganas & 0.558 \\
\hline Paschim Medinipur & 0.592 \\
\hline Purba Medinipur & 0.506 \\
\hline
\end{tabular}

Source: Author's calculation from NSSO 73rd Round data

\section{REGRESSION RESULTS}

To understand the factors on which the efficiency scores depend the efficiency scores of the firms were regressed on some of the socio-economic factors. Here stepwise Tobit regression using Stata software is done. Econometricians are sceptical about the use of OLS in the

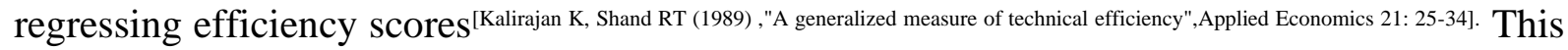
is due to the fact that the efficiency is a truncated variable whose value are bounded between 0 and 1.

The independent variables used are given in the following table:

Table 11 Description of independent variables

\begin{tabular}{|c|l|l|}
\hline Srl. No & \multicolumn{1}{|c|}{ Variable Name } & \multicolumn{1}{|c|}{ Description } \\
\hline 1 & rur & $\begin{array}{l}\text { Rural dummy. Equal to } 1 \text { for firms in rural sector and } 1 \text { for the urban } \\
\text { sector. }\end{array}$ \\
\hline 2. & proprietary & $\begin{array}{l}\text { Proprietary Dummy. Equal to } 1 \text { if the ownership of the firm is of } \\
\text { proprietary type }, 0 \text { otherwise. }\end{array}$ \\
\hline 3. & registered & Dummy. Equal to 1 if the firm have any registration, 0 otherwise. \\
\hline 4. & oae & Enterprise type dummy. 1 if the enterprise is OAE, 0 otherwise. \\
\hline 5 & probfaced & $\begin{array}{l}\text { Problem faced dummy. Equal to } 1 \text { if the firms faced any problem, } 0 \\
\text { otherwise. }\end{array}$ \\
\hline 6. & account & $\begin{array}{l}\text { Aoounts maintained dummy. If the firm maintain account, then value is } 1, \\
\text { 0 otherwise. }\end{array}$ \\
\hline 7. & hhprem & $\begin{array}{l}\text { If the production occurs within the household premises, then value }=1, \\
\text { otherwise } 0 .\end{array}$ \\
\hline 8 & assistance & $\begin{array}{l}\text { If the forms received any government assistance, then this value is } 1,0 \\
\text { otherwise. }\end{array}$ \\
\hline 9 & capital-output ratio & . \\
\hline
\end{tabular}


Table 12 Result of Tobit Regression

$\mathrm{p}<0.0500$

Tobit regression

Log pseudolikelihood $=-18763.925$

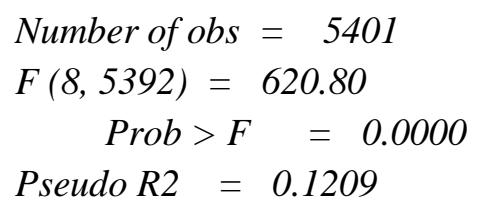

Pseudo $R 2=0.1209$

\begin{tabular}{|l|c|c|c|c|c|c|}
\hline rur & -2.514792 & 0.7406737 & -3.4 & 0.001 & -3.966811 & -1.062772 \\
\hline proprietary & 21.04196 & 1.310883 & 16.05 & 0 & 18.4721 & 23.61182 \\
\hline oae & 59.62359 & 1.041532 & 57.25 & 0 & 57.58176 & 61.66541 \\
\hline probfaced & -2.766848 & 0.7714054 & -3.59 & 0 & -4.279114 & -1.254582 \\
\hline registered & -6.320192 & 0.8619983 & -7.33 & 0 & -8.010057 & -4.630327 \\
\hline account & -3.59205 & 0.8268963 & -4.34 & 0 & -5.213101 & -1.970999 \\
\hline hhprem_dum & -2.03658 & 0.8269706 & -2.46 & 0.014 & -3.657777 & -0.415384 \\
\hline assistance & -7.596939 & 3.207455 & -2.37 & 0.018 & -13.88485 & -1.309032 \\
\hline $\begin{array}{l}\text { capital-output } \\
\text { ratio }\end{array}$ & 0.00073 & 0.0002124 & 3.44 & 0.001 & 0.0003137 & 0.0011463 \\
\hline cons & 23.76385 & 1.641488 & 14.48 & 0 & 20.54587 & 26.98183 \\
\hline & & & & & & \\
\hline /sigma & 25.27918 & 0.3506323 & & & 24.5918 & 25.96656 \\
\hline
\end{tabular}

Source: Author's calculation from NSSO 73rd Round data

Here all the variables are significant at the 5\% level of significance. Among the independent variables only the two variables- proprietary, oae and capital-output ratio have the positive impact of the efficiency score. All other variables have negative impact on the efficiency score. Let us discuss them one by one.

Firms in rural sector has a negative impact on the efficiency score. This is due to the fact that firms in the rural sector faces many problems. On the one hand they cannot acquire inputs easily and on the other hand the faces difficulties in selling their product in comparison to urban firms. Firms with proprietary ownership are better managed in comparison to the partnership firms. Hence the proprietary leads to higher efficiency. If the firm is of OAE type, then efficiency is higher. This is because OAE are family-based firm. The involvement of family labour leads to better efficiency. If the firm is registered the efficiency is less. This means that the stringent law of registration makes these small firms inefficient. Similarly, the small firms which maintain account are less efficient. The complex task of maintaining account lowers efficiency. Production within household premises misses the connection with market and facilities. Thus, those firms which produce within the household premises face lower productivity. Production site is important. We see that assistance variable has a negative impact on the efficiency. Government extends assistance to the needy firms. However, the assistance is not sufficient to pull them out of their problem.

\section{CONCLUSION}

In this paper we calculated technical efficiency of the firms in the unorganised sector in the state of West Bengal in India. We have used the Data Envelopment Analysis (DEA) to find out the efficiency scores of the firms. This nonparametric approach was taken as the firms in this sector varies widely in terms inputs used. Thus, these firms cannot be put under the homogenous 
blanket of the parametric approach. We found efficiency scores varies across sectors and enterprise type. Generally, OAE firms are more efficient than the Establishment firms. Among the factors that explain the efficiency are the factors that hinders the firms with regulation. Location of firms is also an important determinant of efficiency

\section{ACKNOWLEDGEMENT}

I owe Prof. Atanu Sengupta of the University of Burdwan, W.B., for his valuable suggestion and kind help to write this paper.

\section{REFERENCES}

[1] Bairagya, I. (2013). Sub-Contracting and Efficiency of the Informal Sector in India. The Journal of Developing Areas, 47(2), 341-361.

[2] Banker, R. D., Charnes, A., \& Cooper, W. W. (1984). Some Models For Estimating Technical and Scale Inefficiencies in Data Envelopment Analysis. Management Science, 30(9), 10781092.

[3] Berger, S., \& Piore, M. J. (1980). Dualism and Discontinuity in Industrial Societies. In Cambridge University Press.

[4] Capecchi, V. (1989). "The Informal Economy and the Development of Flexible Specialization in Emilia-Romagna" in Portes, Castells and Benton (eds.) The Informal Economy

[5] Cherian, J.; Gaikar, V.; Paul, R.; Pech, R. Corporate Culture and Its Impact on Employees' Attitude, Performance, Productivity, and Behavior: An Investigative Analysis from Selected Organizations of the United Arab Emirates (UAE). J. Open Innov. Technol. Mark. Complex. 2021, 7, 45

[6] Gaikar V. (2013), "Indian Migration: Brain Drain Versus Brain Gain" Episteme: an online Interdisciplinary, Multidisciplinary \& Multi-cultural Journal, Volume 1, Issue 5, March 2013 BCC, Pp. 72-81

[7] Gaikar Vilas B. and Sameer Aziz Lakhani (2019), 'Study of Demographic Variables on Financial Goal of Urban Individuals' in International Journal of Research, Vol. 9 (1), JulyDecember 2019, Pp. 24 - 34.

[8] Gutmann, P. M. (1979). Statistical Illusions, Mistaken Policies. Challenge, 22(5), 14-17. https://doi.org/10.1080/05775132.1979.11470560

[9] Harris, J. R., \& P.Todaro, M. (1970). Migration, Unemployment and Development: A TwoSector Analysis. American Economic Review, 40, 126-142.

[10] Jorgenson, Dale. The Development of a Dual Economy. The Economic Journal, 71, no. 282 (1961): 309-334.

[11] Kalirajan K, Shand RT (1989) ,"A generalized measure of technical efficiency",Applied Economics 21: 25-34

[12] Kanbur, S. M. R., \& McIntosh, J. (1988). Dual Economy Models: Retrospect and Prospect. Bulletin of Economic Research, 40(2), 83-113. https://doi.org/10.1111/j.14678586.1988.tb00257.x

[13] Kathuria, V., Rajesh Raj, S. N., \& Sen, K. (2010). Organised versus unorganised manufacturing performance in the post-reform period. Economic and Political Weekly, 45(24), 55-64.

[14] Lewis, W. A. (1954). Economic Development with Unlimited Supplies of Labour. The Mancherster School, 22(2), 139-191. 
[15] Portes, A., \& Sassen-Koob, S. (1987). Making it Underground: Comparative Material on the Informal Sector in Western Market Economies. American Journal of Sociology, 93(1), 30-61. https://doi.org/10.1086/228705

[16] Rajesh Raj, S. N. (2011). Technical efficiency in the informal manufacturing sector: Firm-level evidence from an Indian State. Journal of South Asian Development, 6(2), 213-232. https://doi.org/10.1177/097317411100600204

[17] Ranis, G., \& Fei, J. C. H. (1961). A Theory of Economic Development. American Economic Review, 51(4), 533-565. https://doi.org/10.1257/aer.98.5.i

[18] Review, 51(4), 533-565. https://doi.org/10.1257/aer.98.5.i

[19] Sengupta, A., Datta, S. K., \& Mondal, S. (2009). Gendering Disguised Unemployment: A Study of Informal Service Sector in India. Sarvekshana, 29(95), 20-39.

[20] Sengupta, A., Datta, S. K., \& Mondal, S. (2011). Male Female Quality Differential in Informal Service Sector: A State Level Study from India. Indian Economic Review, 46(1), 153-176. http://www.jstor.org/stable/23266421

[21] Swaminathan, M. (1991). Understanding the 'Informal Sector': A Survey. In Research Paper (Issue 95).

[22] Varian, H.R. (1984). Microeconomic Analysis, 2nd ed. WW Norton and company, New York.

[23] Ybarra, Josep-Antoni (1989). Informalization in the Valencian Economy: A Model for Underdevelopment. In Portes, Castells and Benton (eds.) The Informal Economy. 